\title{
Developing the Global Engineering Leader at a Leading Engineering Institu- tion in the Southeast
}

\section{Dr. Adjo A Amekudzi-Kennedy, Georgia Institute of Technology}

Professor Adjo Amekudzi-Kennedy's research, teaching and professional activities focus on civil infrastructure decision making to promote sustainable development. She studies complex real-world systems and develops infrastructure decision support systems to promote sustainable development. Kennedy earned a Bachelor of Science in Civil Engineering (Structures) from Stanford University in 1994, a Master of Science in Civil Engineering (Transportation) from Florida International University in 1996; a Master of Science in Civil Infrastructure Systems in 1997, and a Ph.D. in Civil and Environmental Engineering (Infrastructure Systems) from Carnegie Mellon University in 1999. She directs the Infrastructure Research Group (www.irg.ce.gatech.edu) at Georgia Tech, a group whose vision is to develop thought leaders in engineering and policy development for sustainable development. The IRG focuses on the study, development and application of systems method to manage civil infrastructure as assets for sustainable development. Kennedy has developed undergraduate and graduate courses in Systems Engineering, Transportation Asset Management, and Sustainable Development Planning and Evaluation, published extensively on these subjects, and serves on several professional boards and expert panels including the Board on Infrastructure and the Constructed Environment (BICE, U.S. National Research Council) and the International Panel for Climate Change (IPCC, United Nations). She is coauthor of the college textbook Systems Engineering with Economics, Probability and Statistics, J. Ross Publishing, 2012. She serves on the editorial boards for the International Journal of Sustainable Transportation and Transportation in Developing Economies. Kennedy is the founding chair of the Committee on Sustainability and the Environment of the American Society of Civil Engineers' Transportation and Development Institute. She serves on the advisory board of the Integrated Network for Social Sustainability (INSS) and is a member Research Coordination Network (RCN) on Megacities and Sustainability, both sponsored by the National Science Foundation. Kennedy also serves as Associate Chair for Global Engineering Leadership and Research Development at the School of Civil and Environmental Engineering at Georgia Tech, with responsibilities for managing and expanding the School's global education, research and outreach programs and impact. Kennedy and her students have been the recipient of several prestigious awards including the 2009 Recent Alumnus Award given by Carnegie Mellon University to recognize outstanding alumni, and the 2014 Charley V. Wootan Award given by the Transportation Board (National Academies) to recognize the best paper in transportation policy and organization. In her leisure time, Kennedy enjoys spending time with her family, playing the piano and painting.

\section{Prof. Reginald DesRoches, Georgia Institute of Technology}

Reginald DesRoches is the Karen and John Huff School Chair and Professor of Civil and Environmental Engineering at the Georgia Institute of Technology. As School Chair, he provides leadership to a topranked program with 100 faculty and staff and 1,100 students. His primary research interests are in design of resilient infrastructure systems under extreme loads. He has published more than 250 articles in the general area of resilience and seismic risk assessment.

Dr. DesRoches has served as the key technical leader in the United States' response to the Haiti earthquake and led a team of 28 engineers, architects, city planners, and social scientists to study the impact of the earthquake. He has also participated in numerous congressional briefings to underscore the critical role that university research must play in addressing the country's infrastructure crisis and resilience to natural hazards. Dr. DesRoches has served as thesis advisor to 29 Doctoral and 17 Master's thesis students.

Dr. DesRoches has served as Chair of the ASCE Seismic Effects Committee (2006-2010), Chair of the executive committee of the Technical Council on Lifeline Earthquake Engineering (2010), and Board of the Earthquake Engineering Research Institute (EERI). He is currently a member of the executive committee of the National Academy of Sciences Roundtable on Risk, Resilience, and Extreme Events, a member of National Science Foundation (NSF) Engineering Directorate Advisory Committee, and is a member of the National Academies Board on Army Science and Technology (BAST). Dr. DesRoches 
has received numerous awards, including the Presidential Early Career Award for Scientists and Engineers (PECASE) in 2002 - the highest honor bestowed upon scientists and engineers in the early stages of their careers. Most recently, he was a recipient of the 2007 ASCE Walter L. Huber Civil Engineering Research Prize, the 2015 ASCE Charles Martin Duke Lifeline Earthquake Engineering Award, the Georgia Tech Outstanding Doctoral Thesis Advisor Award (2010), and the Georgia Tech ANAK Award (2008). The ANAK award is the highest honor the undergraduate student body can bestow on a Georgia Tech faculty member.

Dr. DesRoches earned his Bachelor of Science in Mechanical Engineering in 1990, a Master of Science in Civil Engineering in 1992, and a Ph.D. in Structural Engineering in 1998 - all from the University of California, Berkeley. He was inducted into Berkeley's Academy of Distinguished Alumni from Civil and Environmental Engineering in 2015.

\section{Dr. Susan E Burns P.E., Georgia Institute of Technology}

Susan E. Burns, Ph.D., P.E., F.ASCE is the Georgia Power Distinguished Professor and Associate Chair for Undergraduate Programs in the School of Civil and Environmental Engineering at the Georgia Institute of Technology. Dr. Burns earned a Bachelor Degree in Civil Engineering B.C.E. (1990), M.S. Civil Engineering (geotechnical) (1996), M.S. Environmental Engineering (1996), and Ph.D. in Civil Engineering (1997), all from Georgia Tech. Prior to joining the faculty at Georgia Tech in 2004, she was a member of the faculty at the University of Virginia for over seven years.

Dr. Burns' research focuses on applications in geoenvironmental engineering, with particular emphasis on the productive reuse of waste materials including dredged sediments, fly ash, and biomass fly ash, treatment of highway stormwater runoff using engineered materials, erosion control of soils on highway rights-of-way, interfacial behavior of organic- and inorganic-coated soils, the transport and behavior of microbubbles in otherwise saturated porous media, and the hydraulic conductivity and consolidation properties of fine-grained soils using seismic piezocone penetration testing (SPCPT).

\section{Dr. Laurence J. Jacobs, Georgia Institute of Technology}

Associate Dean for Academic Affairs, College of Engineering

\section{Ms. Janille A Smith-Colin P.E., Georgia Institute of Technology}

Janille Smith-Colin is a PhD student in Civil and Environmental Engineering (Transportation Systems Engineering) with a minor focus in the School of Public Policy. She is a member of the Infrastructure Research Group (IRG) directed by Dr. Adjo Amekudzi-Kennedy, a group whose vision is to develop thought leaders in engineering and policy for sustainable development. Her research focuses on the study, development, and application of methods that promote sustainable transportation systems. Her most recent work has focused on the development of evidence-based methodologies for transportation asset management, the advancement of theories around transportation systems health, and the exploration of partnering strategies for improved project delivery outcomes. Smith-Colin has provided research support to the Global Engineering Leadership Development Minor, and has served as a one-on-one coach and grand challenges facilitator for the Leadership and Education Development (LEAD) program for the past 3 years. In fall 2016, she will serve as an instructor for the leadership development sections of the GT 1000 first year seminar. Smith-Colin is a two-time recipient of the Dwight David Eisenhower Transportation Fellowship, and was honored with the 2014 WTS/CH2M Hill Partnership Scholarship. She and her colleagues were awarded the 2014 Charley V. Wootan Award given by the Transportation Research Board (National Academies) to recognize the best paper in transportation policy and organization. Smith-Colin earned a Master of Science in Civil Engineering from the University of Wisconsin-Madison in 2006, and a Bachelor of Arts from Lafayette College in 2003.

\section{Dr. Wes Wynens, Georgia Institute of Technology}

Dr. Wes Wynens is the Director of the Leadership Education and Development Program for Student Affairs and serves as an adjunct professor in the School of Public Policy at Georgia Tech. Dr. Wynens has 
more than twenty years of experience in applied leadership development, coaching, and leadership education. His interests are in adaptive leadership and the effects of challenge and loss on leadership capacity. From 2004 to 2010, he was director of State Leadership Development Programs for the Carl Vinson Institute, where he founded the Georgia Leadership Institute and the Executive Leadership Program. He has been a consultant to Deloitte, Coca-Cola, BellSouth, NORTEL, and the Army Corp of Engineers. His professional affiliations include Pi Alpha Alpha, the OD Network, and the International Leadership Association. Dr. Wynens holds a Ph.D. in Public Administration from the University of Georgia with an emphasis on organization and team development.

\section{Dr. Lisa Gail Rosenstein, Georgia Institute of Technology}




\title{
Developing the Global Engineer-Leader at Georgia Institute of Technology
}

\author{
Adjo Amekudzi-Kennedy, Ph.D., Georgia Institute of Technology \\ Reginald DesRoches, Ph.D., Georgia Institute of Technology \\ Susan Burns, Ph.D., Georgia Institute of Technology \\ Wes Wynens, Ph.D., Georgia Institute of Technology \\ Lisa Rosenstein, Ph.D., Georgia Institute of Technology \\ Laurence Jacobs, Ph.D., Georgia Institute of Technology \\ Janille Smith-Colin, Georgia Institute of Technology
}

\begin{abstract}
The Global Engineering Leadership Minor aims to develop global engineer-leaders, that is, engineers who can contribute and lead effectively in domestic and international contexts in solving global grand challenges and other societal problems, working effectively across cultures. The Minor is based on the Global Engineering Leadership Development (GELD) conceptual framework, adapted from the Skills Model of Leadership. The Minor curriculum includes learning and application of leadership theory, enhancement of engineering problem solving skills, development of interpersonal skills (communication, collaboration, ethics, and management), application of systems-level thinking and analysis to global grand challenges, and development of cross-cultural awareness/skills. This framework is informed by the National Academy of Engineering's Vision for the Engineer of 2020 advanced in the early 2000s, and is the basis of the development of the Global Engineering Leadership (GEL) Minor at the Georgia Institute of Technology. The elective 15-credit undergraduate program, completed simultaneously with a bachelor's degree, was developed and approved during the 2014/15 academic year and first offered beginning in the 2015/16 academic year. It is administered in the School of Civil \& Environmental Engineering and serves all undergraduate students in the College of Engineering (COE). The GEL Minor requires students to complete five courses, attend a leadership seminar series, and complete an international work-based, research-based or study-based experience. The minor courses are taught by faculty in the College of Engineering including in-house communications faculty; the School of Public Policy; the Institute's Leadership Education and Development (LEAD) Program, and executive-level engineering practitioners. The pedagogy model integrates leadership instruction into the broader context of global societal grand challenges such as water availability and quality, air quality, urbanization, megaprojects, disasters, transportation, cities and sustainable development. A number of courses have embedded study abroad experiences to foster global awareness, cross-cultural sensitivities and skills, and contextual problem solving. This paper discusses the development of the Global Engineering Leadership Minor at Georgia Tech, focusing on the driving factors, the thinking underlying the program development, the curriculum, and future directions for the program.
\end{abstract}




\section{Background and Objectives}

The Global Engineering Leadership (GEL) Minor is one of three tracks of the Minor in Leadership Studies at the Georgia Institute of Technology, alongside other tracks in Business Management and Public Policy. The GEL Minor was developed during the 2014/15 academic year and first offered in the 2015/16 academic year. It is driven by the Institute and College of Engineering strategic plans, as well as the plans of various engineering schools, and informed by the National Academy of Engineering's Vision for the Engineer of 2020. The program is based on a conceptual framework for Global Engineering Leadership Development adapted from the Skills Model of Leadership and engineering leadership and global engineering education working practices. A 15-credit hour curriculum of coursework with in-course practical experiences and a capstone practicum, the program is administered in the School of Civil \& Environmental Engineering and serves all undergraduate students in the College of Engineering. This paper describes the driving factors, the thinking underlying the development of the minor, curriculum requirements, and future directions including empirical data collection and testing of the conceptual framework, and program assessment.

\section{The Global Engineering Leadership Conceptual Framework}

The program defines the global engineer-leader as an engineer who can contribute and lead effectively in domestic and international contexts in solving global grand challenges and other societal problems, working effectively across cultures. The conceptual framework for Global Engineering Leadership Development (GELD) was developed in order to identify basic attributes of a global engineer-leader, and to direct the development of the Global Engineering Leadership (GEL) Minor curriculum.

The Institute and College of Engineering's strategic plans focus on engineering leadership and global stewardship, as do several of the strategic plans of the various engineering schools. Table 1 provides a list of leadership-focused objectives and strategies within the strategic plans of the Institute, College of Engineering and selected engineering schools reflecting the broad focus on the development of leaders and expansion of global influence. These strategic plan elements are well aligned with the National Academy of Engineers' Vision for the Engineer of 2020, which includes the following attributes (1):

(1) Technical proficiency

(2) Broad education

(3) Global citizenship

(4) Ethical grounding

(5) Ability to lead in business and public service.

These strategic plans and the NAE vision were foundations for the development of the GEL Minor. 
Table 1: Leadership- and Global-Focused Strategic Plan Elements Influencing the Development of the Global Engineering Leadership Minor

Georgia Institute of Technology Strategic Plan (2010 - 2035) (2)

- Georgia Tech will define the technological research University of the $21^{\text {st }}$ century. As a result, we will be leaders in influencing major technological, social and political decisions that address critical global challenges. (Vision)

- Ensure that innovation, entrepreneurship and public service are fundamental characteristics of our graduates (Goal 3)

- $\quad$ Serve in state, national and global leadership positions (Goal 3, Strategy 3)

- Expand our global footprint and influence to ensure we are graduating good global citizens (Goal 4)

- Extend and leverage Georgia Tech's impact around the globe (Goal 4, Strategy 2)

- Embrace and support globally engaged students (Goal 4, Strategy 3)

College of Engineering Strategic Plan (2012 - 2017) (3)

- Ensure that innovation, entrepreneurship and public service are fundamental characteristics of our graduates (Objective 3)

- Expand our global footprint and influence to ensure that we are graduating global citizens (Objective 4)

Civil \& Environmental Engineering (CEE) Strategic Plan (2013/14 - 2017/18) (4)

- Enhance our curriculum and learning pedagogy to prepare our students to become global leaders in addressing the societal grand challenges and identifying opportunities that are at the interface of built, natural and societal systems (Objective 1, Education)

- To empower, inspire and equip CEE students and faculty to be engaged global citizens through public service and outreach that address challenges on the state, national and/or global levels. (Objective 3, Global Public Service \& Outreach)

- Foster an environment in which CEE's status as a local, national and global thought leader in the field is promoted in multiple venues, internally and externally (Objective 5, Leadership)

Industrial Systems and Engineering (ISYE) Strategic Plan (2013 - Present) (5)

- Prepare and train our students to be leaders in industry, academia and government (Objective 1)

- Ensure innovation, entrepreneurship and public service are fundamental characteristics of ISYE graduates (Objective 3)

- Expand ISYE's global footprint and influence to ensure that it is graduating good global citizens (Objective 4)

Mechanical Engineering (ME) Strategic Plan (2010 - Present) (6)

- Develop a flexible curriculum with breadth beyond engineering, requiring fewer courses while ensuring mastery of core engineering classes and foundational sciences, developing leadership skills, emphasizing interdisciplinary collaboration, communication, and student responsibility for configuring education. (Under Objective 2)

- Emphasize international and study abroad experiences (Under Objective 2) 
Secondly, the literature describing engineering leadership development programs in U.S. and international colleges and universities was reviewed. General leadership development programs serving engineering students were not omitted from the review. In developing the GELD framework, particular attention was paid to engineering leadership minors, general leadership minors serving engineering students, and international/global engineering minors or other programs in order to identify an initial set of knowledge and skills considered important in engineering leadership and global engineering development. Several programs were reviewed including Pennsylvania State University’s Engineering Leadership Development Minor, University of Maryland's Minor in Engineering Leadership Development, University of Illinois at Urbana-Champagne's Leadership Studies Minor, Purdue University’s Engineering Leadership Minor, Brigham-Young University’s College of Engineering Global Leadership Program, Massachusetts Institute of Technology’s Bernard M. Gordon Engineering Leadership Program, Northeastern University’s Gordon Engineering Leadership Program, University of Toronto’s Engineering Leadership Education Program, Pennsylvania State University’s International Engineering Certificate Program, University of Maryland's Minor in International Engineering, and University of Toronto's Global Engineering Certificate. (7-20). While definitions of engineering leadership and global engineering education varied, several engineering leadership development programs included the following: (1) a foundational leadership course (addressing theory with practical applications); (2) choice among elective leadership or leadership-oriented courses; (3) practical experience in solving real world problems, and, (4) a capstone experience. Table 2 shows examples of the kind of information that was considered useful in this exercise.

Table 2: Examples of Engineering Leadership Development and International Engineering Programs

\begin{tabular}{|c|c|}
\hline References & Excerpts of Key Information \\
\hline $\begin{array}{l}\text { Engineering Leadership Development Minor } \\
\text { (ELDM), Penn State University, } \\
\text { http://sedtapp.psu.edu/leadership/index.php (7) }\end{array}$ & $\begin{array}{l}\text { Approach: } \\
\text { - Applies learning-by-doing approach to cultivate } \\
\text { leadership skills through working on real-world } \\
\text { projects } \\
\text { Requirements: (18 credit hours) } \\
\text { - Leadership Principles (2 credits) } \\
\text { - Leadership Experience (1 credit) } \\
\text { - Leadership in Organizations ( } 3 \text { credits) of } \\
\text { - International Option } \\
\text { - } \quad \text { Lechnology-based Entrepreneurship (3 credits) } \\
\text { - } \quad \text { Elective courses (6 credits) }\end{array}$ \\
\hline $\begin{array}{l}\text { Minor in Engineering Leadership Development, } \\
\text { University of Maryland, A. James Clark School } \\
\text { of Engineering } \\
\text { http://www.ilp.umd.edu/coursework (8) }\end{array}$ & $\begin{array}{l}\text { Approach: } \\
\text { - Preparation for life-long leadership roles in } \\
\text { education, industry and government } \\
\text { Requirements: (16 credit hours) } \\
\text { - Introduction to Engineering Leadership ( } 3 \text { credits) } \\
\text { - Engineering Project Management ( } 3 \text { credits) }\end{array}$ \\
\hline
\end{tabular}




\begin{tabular}{|c|c|}
\hline & $\begin{array}{cl}\text { - } & \text { International Business Cultures in Engineering and } \\
& \text { Technology (3 credits) } \\
\text { - } & \text { Engineering Leadership Capstone (3 Credits) } \\
\text { - } & \text { Intergroup Dialogue (1 credit) } \\
\text { Notes: } & \text { Elective (with advisor approval) } \\
\text { - } & \text { Maximum of } 6 \text { credits may also be taken toward } \\
\text { - } & \text { student's major } \\
& \text { Maximum of } 6 \text { credits may be taken outside of home } \\
\text { institution }\end{array}$ \\
\hline $\begin{array}{l}\text { Leadership Studies Minor, University of Illinois } \\
\text { at Urbana-Champaign } \\
\text { http://www.illinoisleadership.uiuc.edu/leadershi } \\
\text { p/ (9) }\end{array}$ & $\begin{array}{l}\text { Approach: } \\
\text { - Provides undergraduates in any field of study with } \\
\text { formal instruction on the study of the theory of } \\
\text { leadership and practice } \\
\text { - Uses the Skills-based Model of Leadership } \\
\text { Requirements: ( } 17 \text { - } 18 \text { credits) } \\
\text { - Introduction to Leadership Studies (3 credits) } \\
\text { - Leadership in Groups and Teams (3 credits) } \\
\text { - Organizational Psychology ( } 3 \text { credits) } \\
\text { - Capstone - Collaborative Leadership } \\
\text { - Two Pre-approved Electives }\end{array}$ \\
\hline $\begin{array}{l}\text { International Engineering Certificate Program, } \\
\text { Penn State University } \\
\text { https://www.engr.psu.edu/global/students/IntlEn } \\
\text { grCertificate.htm (18) }\end{array}$ & 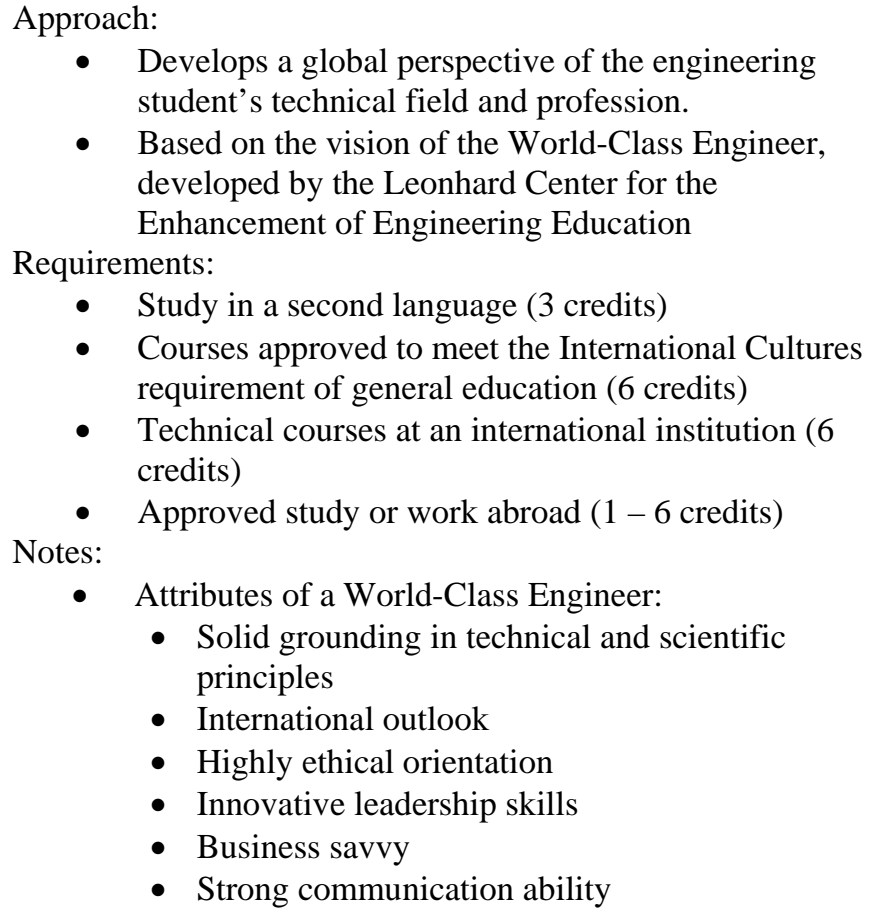 \\
\hline $\begin{array}{l}\text { Minor in International Engineering, University } \\
\text { of Maryland, A. James Clark School of } \\
\text { Engineering } \\
\text { http://www.ilp.umd.edu/coursework (19) }\end{array}$ & $\begin{array}{l}\text { Approach } \\
\text { - Designed to give graduate students the following in } \\
\text { addition to a strong engineering background: } \\
\text { preparation to practice in a global economy; cross- } \\
\text { cultural experience; foreign language abilities } \\
\text { Requirements (15 - } 18 \text { credits) } \\
\text { - International Business Cultures for Engineering and } \\
\quad \text { Technology ( } 3 \text { credits) }\end{array}$ \\
\hline
\end{tabular}






In addition, the literature was searched for broad trends in engineering leadership education and global engineering education. Graham et al. (2010), a study on U.S. and international engineering education programs conducted by professionals at the Bernard M. Gordon Engineering Leadership Program at Massachusetts Institute of Technology between September 2008 and March 2009, provides a useful snapshot overview of engineering leadership education in the U.S. and internationally (13). The report findings show that the vast majority of the 40 programs reviewed were developed in the 2000s. They typically fall into one of two categories: (1) those based around leadership/management theory, often with a strong partnership with the university's business school; and (2) those based around team projects with a global, environmental or service theme. Most non-U.S. programs identified in the review had been in operation for over 10 years and typically fell into one or more of the following categories: (1) those involving coaching of more junior students; (2) those involving industry-based 'real-world' projects, where the entire program is funded through companies sponsoring one or more team; and (3) those based around team projects with a global, environmental or service theme.

The report presents examples of international good practice in engineering leadership education with examples grouped into two categories: (1) explicit programs in which engineering leadership development is the primary and explicit objective; and (2) non-explicit programs, in which engineering leadership development is embedded within a broader program focus. The review uncovers surprisingly limited resources, expertise and formal networks in the field of engineering leadership education, and reports that this finding is in contrast with the related disciplines of engineering entrepreneurship education and global engineering education.

Graham et al. reports that the vast majority of the programs (probably 80-90\%) that focus explicitly on leadership are based in the U.S., demonstrating a distinct divide between the U.S. and the rest of the world in both attitude and approach to engineering leadership education. U.S.-based experts were familiar and comfortable with the concept of targeting leadership as a specific theme in engineering education. However, there was greater discomfort among the nonU.S. interviewees regarding this approach because it was seen to run counter to an educational culture that emphasizes inclusiveness and equality. The growing literature on U.S. engineering education programs describes a wide range of program types and pedagogical approaches (7-20). 
Additionally, a large number of programs identified in Graham et al. operate outside the formal engineering curriculum, in part due to a lack of resources and/or engagement in the field of engineering leadership by the core engineering faculty. In almost every case reviewed, engineering leadership programs were found to be hosted within engineering programs and, despite tensions between the business schools and the engineering schools with respect to who should be "owning” and operating the programs, it was clearly felt that such programs should continue to be hosted within engineering schools in order to provide the required academic and professional contexts for the students to apply and reflect on their developing leadership abilities. Experts in the engineering leadership programs however expressed concern about the ability of current engineering faculty to deliver effective leadership programs and the difficulties of identifying external and suitably qualified staff.

Graham et al.’s study also identifies strong themes in engineering leadership education. The global theme was found to be particularly strong within U.S. programs: the ability to work effectively across cultures in an international sphere was seen by many as an increasingly vital attribute of an engineer-leader, and is reflected in many of the programs. Another strong theme was student empowerment in their own leadership development.

Another study by Cox et al. (2010) reports on several pedagogical practices found for incorporating leadership elements in engineering curricula across a variety of programs in the U.S. (21). These practices include the redesign of courses to add elements that cultivate leadership skills; incorporation of interdisciplinary activities; inclusion of hands-on practical experiences; teamwork (including rotating team leadership); projects requiring the development of communication and presentation skills; and open-ended problems and reflective exercises. Program types identified for delivering engineering leadership development to both undergraduate and graduate students include Bachelor of Science degrees, Associate of Science degrees, specialized certificates, Minors, extended experiences for students, and selected coursework.

In a parallel effort to identify appropriate models to frame global engineering leadership attributes that would define the program, the general and engineering leadership development literature was also consulted. To this end, various leadership theories, hypotheses, principles and models were reviewed $(22,23,24)$ and examined against the leadership attributes articulated by the Institute, College and Schools' strategic plans, the NAE's Vision for the Engineer of 2020, and engineering leadership programs of north American colleges and universities. The Skillsbased Model for Leadership was identified as an appropriate platform as a point of departure for a conceptual framework for global engineering leadership development. The Skills-based Model or Skills Model is a capability model focused on problem-solving -- the main business of engineering -- and offers opportunities to incorporate both engineering and non-engineering attributes of leadership for a more holistic concept of engineering leadership. 
Katz (23) suggested that effective administration (i.e., leadership) depends on three basic personal skills, based on field research in administration and his own firsthand observations of executives in the workplace:

(1) Technical skills,

(2) Human skills, and

(3) Conceptual skills.

Technical skill is knowledge about and proficiency in a specific type of work or activity. It includes competencies in a specialized area, analytical ability, and the ability to use appropriate tools and techniques. Human skill is knowledge about and ability to work with people. Also known as people skills, human skills are the abilities that help a leader to work effectively with followers, peers, and superiors to accomplish the organization's goals. Conceptual skills are the ability to work with ideas and concepts (22).

According to Katz’s Three-Skills Approach, for leaders operating at lower levels of management, technical and human skills are most important. When leaders move into middle management, it becomes important that they have all three skills: technical, human and conceptual skills. At the upper management levels, it is paramount for leaders to exhibit human and conceptual skills (22).

Beginning in the early 1990s, a group of researchers, with funding from the U.S. Army and Department of Defense, set out to test and develop a comprehensive theory of leadership based on problem-solving skills in organizations. They conducted studies over a number of years using a sample of more than 1,800 Army officers, and a variety of new measures and tools to assess the skills of these officers, their experiences and the situations in which they worked. The researchers' main goal was to explain the underlying elements of effective performance. Mumford and colleagues formulated a skill-based model of leadership based on the extensive findings from the project. The model is characterized as a capability model because it examines the relationship between a leader's knowledge and skills (i.e., capabilities) and the leader's performance. Rather than emphasizing what leaders do, the skills approach frames leadership as the capabilities (knowledge and skills) that make effective leadership possible (24).

The skill-based model of Mumford's group has five components: competencies, individual attributes, leadership outcomes, career experiences, and environmental influences. Figure 1 shows the three sets of competencies of Mumford et al.'s Skills Model linked to leadership outcomes including effective problem-solving and overall leadership performance. 




Figure 1: Skills Model - 3 Components (22)

Mumford et al. (2000, p.12) define problem-solving skills as a leader's creative ability to solve new and unusual, ill-defined organizational problems; social judgment skills as the capacity to understand people and social systems - which enables leaders to work with others to solve problems and to marshal support to implement change within an organization; and knowledge as the accumulation of information and the mental structures to organize that information. In the left-hand box, general cognitive ability refers to a person's intelligence; and crystallized cognitive ability is the intellectual ability that is learned or acquired over time. In the right-hand box, effective problem solving and performance are the outcomes of leadership. These outcomes are strongly influenced by the leader's competencies (i.e., problem-solving skills, social judgment skills and knowledge). Leaders who exhibit these competencies increase their chances of solving problems and their overall performance.

The GELD conceptual framework draws heavily from the Skills concept of leadership and the leadership and associated competencies. Given the global engineering focus of the minor, there has been a clear intent from the onset of its development to incorporate both technical (problemsolving) and non-technical leadership competencies as core elements. This intent aligns well with the NAE's identification of technical problem solving as an attribute of the Engineer of 2020. The Skills Model was thus selected as an appropriate platform for the GEL Minor because its keystone is problem-solving and it offers the opportunity to incorporate explicitly technical and non-technical competencies as part of an engineering leadership development framework.

Over and above the three competencies offered by the Skills Model, two additional competencies were considered as relevant in global engineering leadership development: (1) the knowledge and application of leadership theory; and, (2) the ability to work effectively across cultures. These competencies align well with the NAE's Vision for the Engineer of 2020, which calls for engineers who think of themselves as global citizens. They also align well with the Institute, College of Engineering and Engineering Schools' Strategic Plans that call for the development of 
graduates who can lead in a global context (Table 1), as well as the global focus of multiple engineering leadership education programs in U.S. institutions.

The GEL development framework (Figure 2) thus includes the following five key competencies:

(1) Leadership skills

(2) Engineering problem-solving skills

(3) Interpersonal skills

(4) Conceptual skills

(5) Cross-Cultural Awareness/Skills

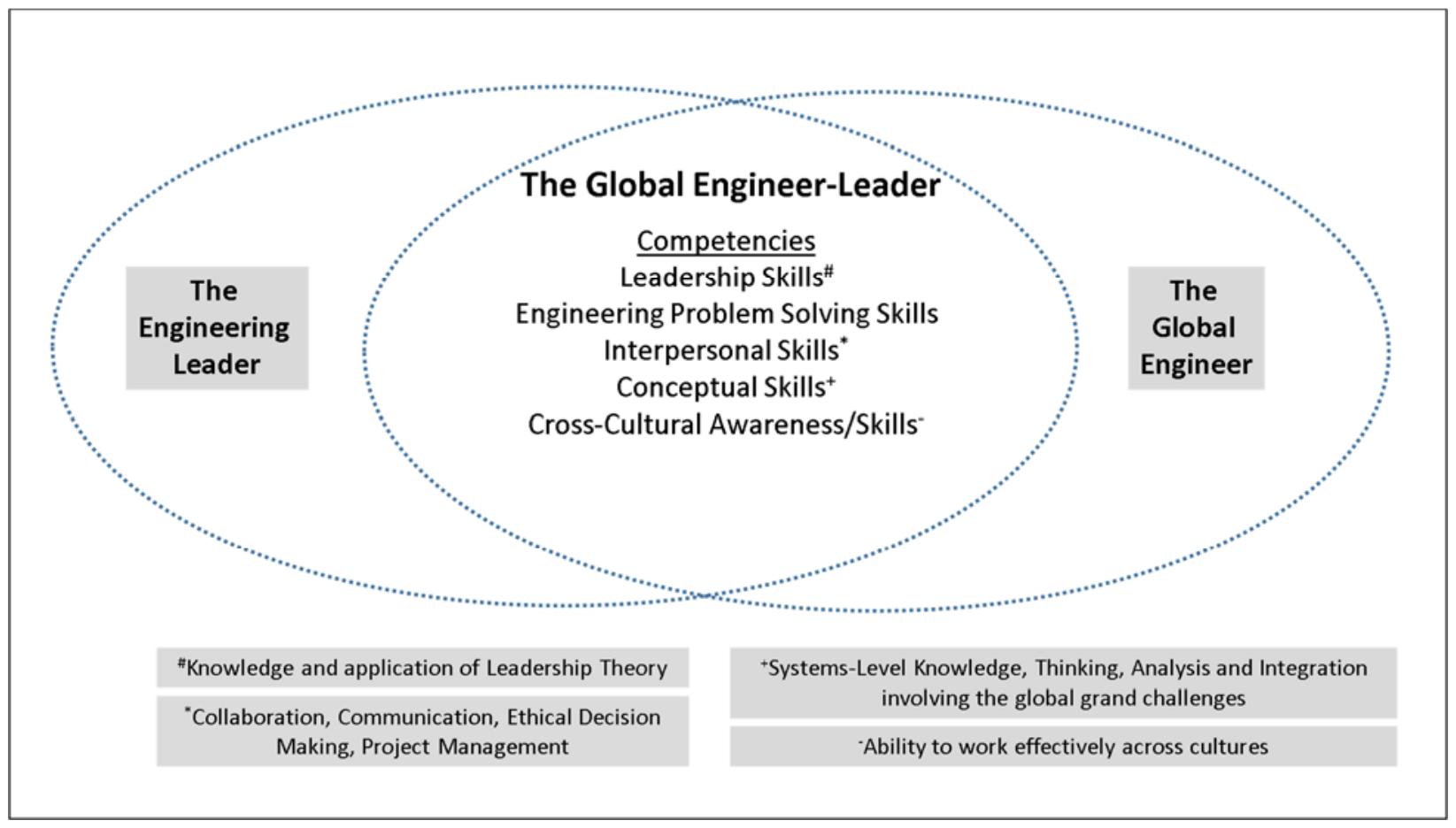

Figure 2: The Global Engineering Leadership Development Conceptual Framework

Rottmann et al.'s research highlights implications of defining engineering leadership development programs within and outside of technical engineering content (25). Based on research conducted by researchers at the Institute for Leadership Education in Engineering (ILEAD) at University of Toronto, this paper presents a grounded theory study that makes a case for grounding leadership theory in engineers' professional identities, that is, professionally recognized forms of engineering influence. To this end, the study identifies the following characteristics of engineering leadership:

(1) Technical mastery (related to technical skills)

(2) Collaborative optimization (related to interpersonal skills)

(3) Organizational innovation (related to conceptual skills) 
The study, grounded in the experiences and perspectives of engineers and human resource professionals, highlights the centrality of engineers' professional identities and their conceptions of leadership to their acceptance or rejection of a leadership identity. It finds that without merging engineering identity with professionally-relevant forms of influence, engineers are likely to resist leadership for themselves and for their colleagues. So long as these two key elements are merged, engineers are willing and able to accept leadership as a legitimate part of their work. The study suggests the importance of explicitly recognizing and cultivating technical competence as an integral component of engineering leadership competencies, given the fundamentally technical nature of engineering. This framework aligns well with the thinking that undergirds the GEL development framework. The GELD framework was the basis for the development of the GEL Minor curriculum, presented in the next section.

\section{The Global Engineering Leadership Minor}

Program \& Curriculum Description: The Global Engineering Leadership Minor is a 15-credit undergraduate program completed simultaneously with a bachelor's degree. The minor program requires students to complete five courses, attend a leadership seminar series, and complete a global practicum, that is, an international work, study or research-based experience. Up to six credit hours of courses taken in the minor may also be used to fulfill technical or free electives in the student's major program of study. Table 3 shows the four main types of courses required to complete the GEL minor informed by the five categories of engineering leadership competencies identified for global engineering leadership development (Figure 1).

The Foundations of Leadership (Foundations) course introduces the students to leadership theory and cultivates their awareness of different leadership styles, which allows them to identify their particular style of leadership and apply different styles of leadership in various contexts. This course is taught by faculty from the School of Public Policy and the Office of Leadership Education \& Development, and is required for all students in the Leadership Minor program.

The Global Engineering Leadership and Management (GELM) course introduces students to leadership and management within an engineering context, with a primary focus on how an engineering company is started and what cultural, ethical, business and economic factors must be considered when expanding a company internationally. To this end, the course also addresses the following questions: (1) What global grand challenges matter in the world today? (2) What is leadership and what does it mean in a global context? (3) How do you become a cosmopolitan leader, rooted in one culture but able to operate effectively in others? Communication instruction is integrated throughout the course. This course is required for all students in the GEL Minor and is taught by a team of instructors that includes faculty in the College of Engineering including in-house communications faculty; and the School of Public Policy and the Office of Leadership Education and Development. In addition to integrating leadership and communications faculty, executive-level engineering practitioners with global engineering leadership experience are fully integrated and involved in the course design and delivery. 
The third category of courses, the Global Engineering Grand Challenge courses, are elective courses focused on selected global societal grand challenges and their engineering leadership opportunities. These courses have leadership development activity embedded in them to enable the development of leadership awareness and skills in the context of engineering problemsolving. Students are required to select three of the grand challenge courses as part of their program. These courses are led by engineering faculty with input from faculty in the Office of Leadership Education and Development to create contextually-relevant embedded leadership development activities within the course.

The global practicum involves a work-based, study-based or research-based engineering experience in a foreign culture to enable the student to apply and further cultivate leadership and cross-cultural awareness and skills. Finally, the students are also required to attend a leadership seminar series with speakers identified as engineering leaders in a global context. Up to six credit hours of courses taken in the minor may also be used to fulfill technical or free electives in the student's major program of study. Table 3 summarizes the course requirements for the Minor, including a summary of the course content and the leadership competency areas it addresses.

Table 3: Global Engineering Leadership Minor: Examples of Engineering Leadership Competencies

\begin{tabular}{|c|c|c|}
\hline $\begin{array}{l}\text { Course } \\
\text { Category }\end{array}$ & Course & $\begin{array}{l}\text { Summary }^{*} \\
\text { Competency Areas }\end{array}$ \\
\hline Foundations & $\begin{array}{l}\text { - Foundations of Leadership (3 } \\
\text { credits) }\end{array}$ & $\begin{array}{l}\text { Leadership theory and practice } \\
\text { Leadership knowledge and skills development; } \\
\text { Interpersonal skills development, Conceptual skills } \\
\text { development }\end{array}$ \\
\hline Foundations & $\begin{array}{l}\text { - Global Engineering } \\
\text { Leadership \& Management (3 } \\
\text { credits) }\end{array}$ & $\begin{array}{l}\text { Leadership skills for engineers, Development of } \\
\text { engineering company, Expansion of engineering company } \\
\text { internationally } \\
\text { Leadership knowledge development; Interpersonal skills } \\
\text { development, Conceptual, Cross-cultural awareness } \\
\text { development }\end{array}$ \\
\hline $\begin{array}{l}\text { Global } \\
\text { Engineering } \\
\text { Grand } \\
\text { Challenge }\end{array}$ & $\begin{array}{l}\text { - Environmental Technology in } \\
\text { Developing Countries (3 } \\
\text { credits) } \\
\text { - Megaprojects and } \\
\text { Construction Management (3) } \\
\text { - International Disaster } \\
\text { Reconnaissance Studies (3) }\end{array}$ & $\begin{array}{l}\text { Technologies to assess air and water quality in developing } \\
\text { regions } \\
\text { Leadership knowledge development, Engineering problem } \\
\text { solving; Interpersonal skills development; Conceptual } \\
\text { skills development; Global knowledge/awareness } \\
\text { development; Cross-cultural skills development } \\
\text { Megaprojects and construction management } \\
\text { Leadership knowledge development; Engineering } \\
\text { problem-solving, Interpersonal skills development, } \\
\text { Conceptual skills development, Global } \\
\text { knowledge/awareness development; Cross-cultural } \\
\text { awareness development } \\
\text { Studies on international disaster reconnaissance } \\
\text { Leadership knowledge development; Engineering } \\
\text { problem-solving, Interpersonal skills development, }\end{array}$ \\
\hline
\end{tabular}




\begin{tabular}{|c|c|c|}
\hline & $\begin{array}{l}\text { - Sustainable Transportation } \\
\text { Abroad (3) } \\
\text { - Sustainable Cities (3) }\end{array}$ & $\begin{array}{l}\text { Conceptual skills development, Global } \\
\text { knowledge/awareness development; Cross-cultural skills } \\
\text { development } \\
\text { Studies on sustainable public transportation in major cities } \\
\text { Leadership knowledge development; Engineering } \\
\text { problem-solving, Interpersonal skills development, } \\
\text { Conceptual skills development, Global } \\
\text { knowledge/awareness development, Cross-cultural skills } \\
\text { development } \\
\text { Studies on cities: sustainable, unsustainable, global } \\
\text { Leadership knowledge development; Engineering } \\
\text { problem-solving, Interpersonal skills development, Big } \\
\text { picture development, Global awareness/cross-cultural } \\
\text { skills development }\end{array}$ \\
\hline Capstone & - Global Engineering Practicum & $\begin{array}{l}\text { Work abroad, research abroad, study abroad, internship } \\
\text { abroad, service-based learning abroad } \\
\text { Application of leadership knowledge; Leadership skills } \\
\text { application and development; Engineering problem- } \\
\text { solving, Interpersonal skills application and development, } \\
\text { Conceptual skills application and development, Global } \\
\text { knowledge application, Cross-cultural skills application } \\
\text { and development }\end{array}$ \\
\hline Seminar & - Hyatt Leadership Seminar & $\begin{array}{l}\text { Exposure to/interaction with global engineer-leaders } \\
\text { Interpersonal skills application and development, } \\
\text { Conceptual skills development, Global } \\
\text { knowledge/awareness development }\end{array}$ \\
\hline
\end{tabular}

*Expanded course descriptions available at: http://ce.gatech.edu/academics/undergraduate/leadership-minor

Contextually-appropriate leadership development activities, embedded in each of the global societal grand challenge courses, are intended to teach leadership knowledge or cultivate leadership skills within the students in the context of the engineering material they are studying. Table 4 shows examples of such leadership development activity developed in a workshop for the primary instructors of the grand challenge courses with faculty from the Office of Leadership Education and Development.

Table 4: Leadership Awareness/Skills Development Activities in GEL Minor Global Grand Challenge Courses: Examples

\begin{tabular}{|c|c|c|}
\hline Course & Leadership Competencies & Course Activities/Assignments \\
\hline $\begin{array}{l}\text { Environmental } \\
\text { Technology in } \\
\text { Developing } \\
\text { Countries }\end{array}$ & $\begin{array}{l}\text { Interpersonal Skills - } \\
\text { Collaboration }\end{array}$ & $\begin{array}{ll}\text { - } & \text { Introduction to Team Portal (Presentation on } \\
\text { online tool) } \\
\text { - } & \text { Effective Team Work (Presentation) } \\
\text { - } & \text { Personality Assessment (Exercise) } \\
\text { - } & \text { Development of Team Charter (Report) } \\
\text { - } & \text { Midterm Team Evaluation (Exercise) }\end{array}$ \\
\hline
\end{tabular}




\begin{tabular}{|c|c|c|}
\hline & $\begin{array}{l}\text { Global Awareness/Cross- } \\
\text { Cultural Skills } \\
\text { Conceptual skills - } \\
\text { Leadership in the context of } \\
\text { New Technologies }\end{array}$ & $\begin{array}{ll}\text { - } & \begin{array}{l}\text { Overseas fieldwork with cultural immersion } \\
\text { (Exercises) }\end{array} \\
\text { - } & \begin{array}{l}\text { Reflection on cultural differences influencing } \\
\text { work output (Report) }\end{array} \\
\text { - } & \begin{array}{l}\text { How local leadership emerges in response to } \\
\text { technical systems (Discussion) }\end{array}\end{array}$ \\
\hline $\begin{array}{l}\text { International } \\
\text { Disaster } \\
\text { Reconnaissance } \\
\text { Studies }\end{array}$ & $\begin{array}{l}\text { Interpersonal Skills - } \\
\text { Collaboration } \\
\text { Global Awareness/Cross- } \\
\text { Cultural Skills } \\
\text { Conceptual skills - } \\
\text { Leadership in Crisis Situations }\end{array}$ & 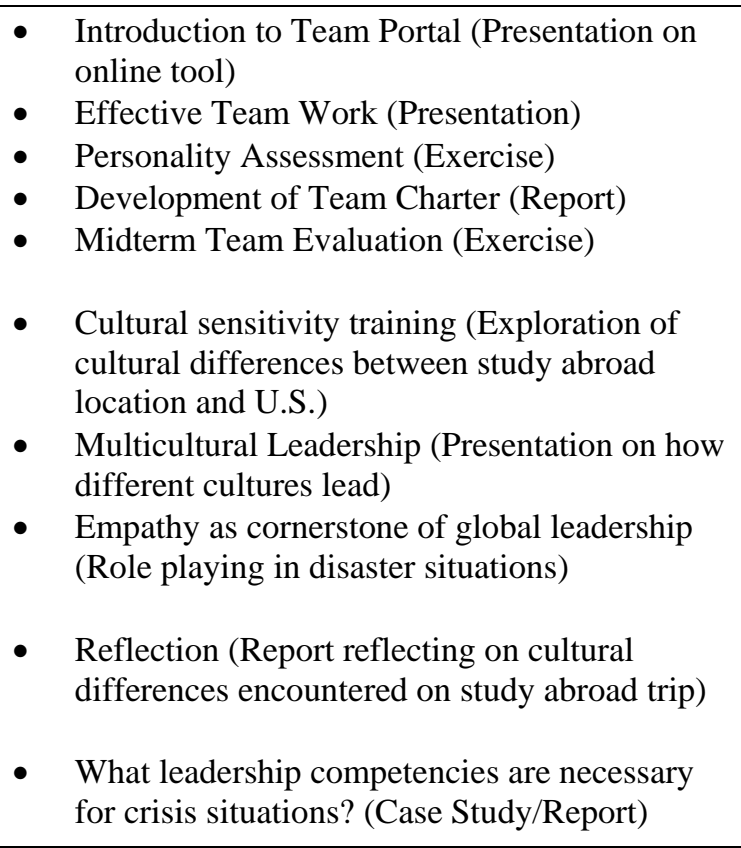 \\
\hline $\begin{array}{l}\text { Megaprojects and } \\
\text { Construction } \\
\text { Management }\end{array}$ & $\begin{array}{l}\text { Interpersonal Skills - } \\
\text { Collaboration } \\
\text { Program/People Management } \\
\text { Conceptual skills - } \\
\text { Ethical Considerations in the } \\
\text { Development of Large-Scale } \\
\text { Multi-National Projects }\end{array}$ & $\begin{array}{ll}\text { - } & \text { Introduction to Team Portal (Presentation on } \\
\text { - } & \text { Enline tool) } \\
\text { - } & \text { Personality Assessment (Exercise) } \\
\text { - } & \text { Development of Team Charter (Report) } \\
\text { - } & \text { Midterm Team Evaluation (Exercise) } \\
\text { - } & \text { Case Study of Best Practices/Lessons Learned } \\
\text { for selected megaprojects, e.g., Panama Canal, } \\
\text { Boston Central Artery Tunnel } \\
\text { - Course material provides opportunities for } \\
\text { students to learn about best practices in } \\
\text { community engagement and stakeholder } \\
\text { management. } \\
\text { Ethical Issues in the Development of } \\
\text { Megaprojects (Team-based exploration/Report) }\end{array}$ \\
\hline
\end{tabular}


Global Engineering Leadership Development Team: The GELD Team is led by the Associate Chair for Global Engineering Leadership and Research Development (GEL\&RD) in the School of Civil \& Environmental Engineering working closely with the Director of the Institute's Office of Leadership Education and Development (LEAD), several College of Engineering (COE) faculty, in-house Communications faculty, faculty in the School of Public Policy, the Director and staff of the Office of International Education, the Registrar and staff in the Office of the Registrar, and the Associate Director of the Office of Assessment, COE alumni and students in the GEL Minor program.

Program Support: Endowed by an alumnus of the School of Civil \& Environmental Engineering (CEE), the Joe S. Mundy Global Learning Endowment offers students the opportunity to participate in an international educational and cultural experiences while at Georgia Tech. The program allows students to be engaged in a wide variety of international experiences including work-abroad, research-abroad and study-abroad. Several of the global grand challenge courses involve embedded study abroad experiences, which allows students to engage in contextual engineering problem solving and cross-cultural development. Eligible students in the GEL Minor may apply for scholarships from the Mundy Learning Endowment. Also endowed by a CEE alumnus, the Kenneth Hyatt Distinguished Alumni Leadership Speaker Series brings leaders of influence to give inspirational lectures to the GT community. GEL Minor students are required to attend these lectures.

Program Stakeholders: The GEL Minor development team includes a broad range of stakeholders. Faculty and students in the School of CEE worked with the College of Engineering and the Institute's Office of International Education to develop the GELD conceptual framework and the GEL Minor curriculum, in conjunction with the Office of the Registrar and the Office of International Education. GELD faculty with graduate student assistants are working with the Office of Assessment to develop an assessment framework and instrument for the GEL Minor. In addition, GELD faculty with graduate student assistance have initiated work with the Office of Leadership Education and Development to design empirical studies to test and refine the GELD conceptual framework over time. The CEE external advisory board has played an important advisory role, advocating for a Leadership Minor in Engineering before its development.

Program Assessment: Initial work on program assessment began in the spring 2015 with the objective of developing a framework and tool that enables faculty to assess student competencies in technical problem solving, leadership skills, interpersonal skills, conceptual skills and cross cultural awareness/skills across the courses that constitute the Minor program. This work has focused on defining program operational objectives and goals, and student learning outcomes for the program. The assessment framework will identify the courses and learning activities that support each program objective as well as measures for tracking progress toward achieving 
student learning outcomes. The assessment framework is expected to illustrate how course assessment measures collectively address the global engineering leadership competencies.

Conceptual Framework Validation: Data collection for validating and refining the GELD conceptual framework will occur as students graduate and begin their careers. This work will involve the development of empirical studies to collect data that tests the leadership effectiveness of GEL Minor graduates in their careers relative to graduates who were not enrolled in the GEL Minor or other formal leadership development program.

\section{Future Directions}

There are multiple ongoing and planned program development initiatives for the Global Engineering Leadership Minor, in both the short- and long-term. Four such initiatives are discussed here. First, work has begun to expand the global grand challenge course offerings within the minor to include courses with lead instructors from additional engineering schools. These course instructors will work with the Office of Leadership Education and Development to develop and include specific leadership development content and activities within their courses. As appropriate, some of these courses may include an international travel component. Second, work has begun on thinking through the empirical data collection and studies that will be used to test and refine the GELD framework as students graduate and begin their careers. Additionally, developed as part of the 10-year Southern Association of Colleges and Schools (SACS) reaffirmation of accreditation process, the Institute's Quality Enhancement Plan (QEP) transforms undergraduate educational experiences and enhances student learning in a tangible way. The 2016-2025 QEP's theme: “creating sustainable communities” integrates sustainability concepts and community involvement into academic programs and provides opportunities for undergraduate students to learn and serve through engagement with content and context. The objectives of the Serve*Learn*Sustain QEP initiative and the Global Engineering Leadership Minor dovetail. Future efforts will aim to increase the community engagement elements of the minor courses. Finally, the GELD Team will continue to refine the program as formal and informal feedback is obtained from the Leadership Minor students, faculty and other stakeholders.

\section{Concluding Remarks}

The Global Engineering Leadership Minor aims to develop global engineer-leaders, engineers who can contribute and lead effectively in domestic and international contexts in solving global grand challenges and other societal problems, working effectively across cultures. It is driven by the Institute's vision to develop engineers who are leaders locally, nationally and internationally, and responds to the National Academy of Engineers' Vision for the Engineer of 2020. This vision calls for engineers who are technically proficient and broadly educated, who think of themselves as global citizens, who are ethically grounded, and who can lead in business and public service. The minor cultivates leadership, engineering problem-solving, interpersonal, 
conceptual and cross-cultural skills in engineering undergraduate students at Georgia Tech. To earn the minor, students complete 15 credits of course work, a leadership seminar and a global practicum. Up to six credits of course work for the minor may be counted toward the student's major requirements. Students are required to take two foundations courses: one in leadership theory and practice, and the other in global engineering leadership and management. Next, the Minor students select 9 credits of course work from engineering grand challenge courses that address global grand challenges, identify leadership opportunities for addressing these challenges, and cultivate associated global awareness and leadership skills. For their capstone experience, students are required to engage in semester-long work, study or research in an international setting where they can apply the leadership, problem solving, interpersonal, conceptual and cross-cultural skills they have learned and developed. The Minor students are also required to attend the Hyatt Leadership Series, which brings a global engineer-leader to deliver an inspirational lecture to the Georgia Tech community every fall and spring. Future work includes development and application of a program assessment framework, and data collection to empirically test and refine the conceptual framework for Global Engineering Leadership Development.

\section{Acknowledgements}

The authors acknowledge the following individuals for their important contributions to the development of the Global Engineering Leadership Minor program: Rudy Bonaparte, Joe Brown, Baabak Ashuri, David Frost, Kari Watkins, John Koon, Wayne Clough, Amy Henry, Tristan Utschig and Reta Pikowsky. 


\section{References}

1. National Academy of Engineering. The Engineer of 2020 - Vision of Engineering in the New Century, The National Academies Press, Washington, D.C., 2004.

2. Georgia Institute of Technology. (2010). Designing the Future - A Strategic Vision and Plan (Georgia Tech Strategic Plan).

3. College of Engineering, Georgia Institute of Technology, Defining Tomorrow - A Strategic Plan, 2012 2017.

4. School of Civil \& Environmental Engineering, Georgia Institute of Technology, Five-Year Strategic Plan, November 2013.

5. Stewart School of Industrial \& Systems Engineering. Engineering Our Future: A Strategic Plan, 2010.

6. The George W. Woodruff School of Mechanical Engineering, Georgia Institute of Technology. Strategic Plan, Discerning and Shaping Excellence for the $21^{\text {st }}$ Century, September 24, 2010

7. Pennsylvania State University, Engineering Leadership Development Minor (ELDM). Accessed at: http://sedtapp.psu.edu/leadership/index.php, December 28, 2015.

8. Schuhmann, R. J., Maston, J. V., Lang, D. H., Soper, J. G., and D. H. Horner, Jr. Engineering Leadership Education - The Path Forward. 122 ${ }^{\text {nd }}$ ASEE Annual Conference \& Exposition, June 14-17, 2015. Seattle, WA. American Society for Engineering Education.

9. University of Maryland, A. James Clark School of Engineering. Minor in Engineering Leadership Development. Accessed at: http://www.ilp.umd.edu/coursework, December 28, 2015.

10. University of Illinois at Urbana Champaign. Leadership Studies Minor, Accessed at: http://www.illinoisleadership.uiuc.edu/leadership/, December 28, 2015.

11. Osagiede, A.; Cox. M. F., and B. Ahn. Purdue University's Engineering Leadership Program: Addressing the Shortfall of Engineering Leadership Education. $120^{\text {th }}$ ASEE Annual Conference \& Exposition, June 2326, 2013, Atlanta, GA. American Society for Engineering Education

12. Brigham-Young University - Ira A. Fulton College of Engineering and Technology - Weidman Center for Global Leadership. Accessed at: http://www.et.byu.edu/weidman-center, March 18, 2016.

13. Graham, R., Crawley, E. and B. R. Mendelsohn. Engineering leadership education: A snapshot review of international good practice. White paper sponsored by the Bernard M. Gordon-MIT Engineering Leadership Program, 2009.

14. Bernard M. Gordon - Massachusetts Institute of Technology Engineering Leadership Program. Accessed at: http://gelp.mit.edu/, May 2015.

15. The Gordon Engineering Leadership Program at Northeastern University, Accessed at: http://www.northeastern.edu/gordonleadership/about-the-institute/curriculum, March 18, 2016.

16. Pitts, S., Klosterman, S. and S. McGonagle. A Successful Approach to Educating of Engineering Leaders at the Graduate Level. Proceedings for the 2013 Canadian Engineering Education Association Conference (CEEA13), Montreal, QC, June 17-20, 2013.

17. University of Toronto, Institute for Leadership Education in Engineering (ILEAD). Accessed at: http://ilead.engineering.utoronto.ca/about-ilead/what-is-engineering-leadership-education/, March 18, 2016.

18. Pennsylvania State University, International Engineering Certificate Program. Accessed at: https://www.engr.psu.edu/global/students/IntlEngrCertificate.htm, December 28, 2015.

19. University of Maryland, A. James Clark School of Engineering. Minor in International Engineering. Accessed at: http://www.ilp.umd.edu/coursework, December 28, 2015.

20. University of Toronto, Center for Global Engineering. Certificate in Global Engineering. Accessed at: http://ilead.engineering.utoronto.ca/about-ilead/our-vision-mission-values/, March 18, 2016.

21. Cox, M. F., Cekic, O., \& S. G. Adams. Developing Leadership Skills of Undergraduate Engineering Students: Perspectives from engineering faculty, Journal of STEM Education, 11(3\&4), Leadership Issue: 22-33, 2010.

22. Northouse, P. G. (2016). Leadership - Theory and Practice, $7^{\text {th }}$ Edition, Sage Publications.

23. Katz, R. L. (1955). Skills of an effective administrator. Harvard Business Review, 33(1), 33-42.

24. Mumford, M.D., Zaccaro, S. J., Harding F. D., Jacobs, R. O., \& Fleishman E. A. (2000). Leadership skills for a changing world: Solving complex social problems. Leadership Quarterly, 11(1), 11-35.

25. Rottmann, C., Sacks, R., and D. Reeve. Engineering Leadership: Grounding leadership theory in engineers' professional identities, Leadership. 0(0) 1-23, DOI: 10.1177/1742715014543581, July 15, 2014, lea.sagepub.com. 